\title{
Basic Results of Long-Term Makrozoobenthos Studies in Lakes Naroch, Myastro, and Batorino (Belarus)
}

\author{
Oleg A. Makarevich* \\ Belarusian State University \\ 4 Nezavisimosty, Minsk, 220030, Belarus
}

Received 26.11.2016, received in revised form 19.08.2017, accepted 29.11.2017, published online 01.02.2018

The article analyzes the trends in the changes of taxonomic structure, density, and biomass of the macrozoobenthos complex and its dominant groups in lakes Naroch, Myastro, and Batorino for the period from 1947 to 2015. The research was carried out at the G.G. Vinberg Naroch Biological Station. In the studied lakes 394 taxa of animals classified as macrobenthic invertebrates were recorded for the entire observation period. The most diverse composition of zoobenthic organisms was in mesotrophic Lake Naroch, in which 373 taxa were found; in eutrophic Lake Myastro and in high-eutrophic Lake Batorino 223 and 155 taxa, respectively, were found. The average-weighted values of the total biomass and density of zoobenthos for the lakes during the studied years were 15.67 and 1.48 in lake Naroch, 12.47 and 1.58 in lake Myastro, and $9.73 \mathrm{~g} / \mathrm{m}^{2}$ and 0.90 thousand ind $/ \mathrm{m}^{2}$ in lake Batorino. The structural organization of benthic communities in these lakes indicates their belonging to the chironomid type.

Keywords: Lake Naroch, Lake Myastro, Lake Batorino, macrozoobenthos, biomass, density, observation period, benthification.

Citation: Makarevich O.A. Basic results of long-term makrozoobenthos studies in lakes Naroch, Myastro, and Batorino (Belarus). J. Sib. Fed. Univ. Biol., 2019, 12(2), 180-195. DOI: 10.17516/1997-1389-0038.

(C) Siberian Federal University. All rights reserved

* Corresponding author E-mail address: oleg_mak69@mail.ru 


\title{
Основные результаты многолетних исследований макрозообентоса озер Нарочь, Мястро, Баторино (Беларусь)
}

\author{
О.А. Макаревич \\ Белорусский государственный университет \\ Беларусь, 220030, Минск, пр. Независимости, 4
}

\begin{abstract}
В статье проанализированы тенденции изменения таксономической структуры, плотности, биомассы комплекса макрозообентоса и его доминирующих групп в оз. Нарочь, Мястро, Баторино за период исследований с 1947 по 2015 г2., проводившихся на Нарочанской биологической станции им. Г.Г. Винберга. В изучаемых озерах за весь период наблюдений отмечено 394 таксона животных, отнесенных к макробентосным беспозвоночным. Наибольшим разнообразием зообентосных организмов отличается мезотрофное оз. Нарочь, в котором вылвлено 373 таксона, в эвтрофном оз. Мястро обнаружено 223 таксона, в высокоэвтрофном оз. Баторино - 155 таксонов. Величины средневзвешенных общих биомасс и плотности поселения зообентоса в иелом для озер за рассматриваемые годы исследований имеют следующие показатели: в оз. Нарочь - 15, 67 и 1,48, в оз. Мястро - 12,47 и 1,58, в оз. Баторино -

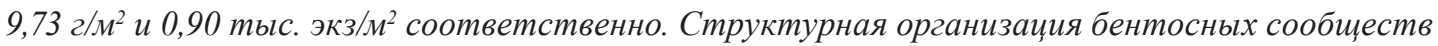
в этих озерах указывает на их принадлежность к хирономидному типу.
\end{abstract}

Ключевые слова: озеро Нарочь, озеро Мястро, озеро Баторино, макрозообентос, биомасса, плотность, периоды наблюдений, бентификаиия.

\section{Введение}

Озера Нарочанской группы в последние десятилетия претерпевают значительные изменения в структурной и функциональной организации их экосистем. Вектор эволюции озер с середины 80-х гг. прошлого века сменился с эвтрофирования на деэфтрофирование, что привело к сдвигам в направленности и интенсивности потоков вещества и энергии. С 90-х гг. начался интенсивный процесс бентификации в исследуемых водоемах. Есть основания предполагать, что роль донных сообществ в функционировании экосистем Нарочанских озер многократно возросла. Появление и массовое развитие дрейссены также оказывает воздействие на все звенья водной экосистемы, вызывая перестройки и в комплексе бентосных сообществ. В связи с этим анализ изменений структуры бентоса и его количественная оценка на протяжении ряда лет представляют научный и практический интерес.

Данная публикация является первой попыткой обобщить разрозненные и нерегулярные исследования макрозообентоса оз. Нарочь, Мястро, Баторино, выполненных разными специалистами в разные годы, а также собственные исследования автора (с 1997 г. по настоящее время). Выводы, приведенные в статье, отражают только основные результаты проведенного обобщения доступных материалов и намечают возможные перспективы 
дальнейших исследований макрозообентоса этих всемирно известных и весьма значимых во многих отношениях для Беларуси озер.

\section{Материалы}

Первые данные по макрозообентосу Нарочанских озер были получены в 1947 г. М.М. Драко (1953). За период работ, проведенных им в 1947-1951 гг,, автор собрал и обработал на оз. Нарочь 291 количественных и 250 качественных проб, на оз. Мястро - 137 и 46, на оз. Баторино - 96 и 12. Режимные наблюдения за макробентосом Нарочанских озер в период с 1959 по 1965 гг. осуществлялись И.П. Арабиной (1968). Ею было отобрано 895 проб во время стационарных наблюдений на Нарочанской биологической станции: из них 370 проб собрано в 1959 г. и 525 проб в 1964-1965 гг. В 1960-1963 гг., не принимая непосредственного участия в отборе проб, И.П. Арабина в своей кандидатской диссертации проанализировала 865 проб, отобранных старшим лаборантом биологической станции А.И. Сергеевым.

На протяжении 1966-1994 гг. макрозообентос Нарочанских озер изучался многими другими исследователями. С.И. Гавриловым и И.И. Десятиком по результатам их исследований были защищены кандидатские диссертации (Гаврилов, 1969; Десятик, 1975). С.И. Гавриловым с 15 февраля 1966 г. по 6 июня 1967 г. было отобрано на 17 станциях оз. Мястро 270 проб и на 12 станциях оз. Баторино - 20 проб зообентоса. В 1967-1969 гг. И.И. Десятиком было собрано и обработано на оз. Нарочь 540 количественных и 26 качественных проб, на оз. Мястро - 300 и 20, на оз. Баторино - 60 и 16 соответственно. По Программе экологического мониторинга Нарочанских озер 1975-1994 гг. были собраны и обработаны пробы С.И. Гавриловым за 1975-1977 гг. (Экологическая система...,
1985); В.П. Ляхновичем и Н.Г. Еремовой за 1983-1990 гг. и студентами кафедры экологии БГУ: в 1983 г. - Я.С. Григорцевич, в 1992 г. Е.В. Коровченко (Остапеня и др., 1993; Остапеня и др., 1994а, 1994б); Н.Г. Еремовой и О.А. Орловской за 1994 г. (неопубликованные данные).

С 1997 г. по настоящее время ежегодно проводятся наблюдения за макрозообентосом Нарочанских озер автором настоящей работы. В оз. Нарочь пробы отбираются на 9 стационарных станциях, на озерах Мястро и Баторино - на 6 станциях в каждом. В некоторые годы программа расширяется отбором дополнительных проб в различных биотопах прибрежной и глубинной частей озер. Результаты исследований публикуются с 2006 г. в ежегодных выпусках Бюллетеня экологического состояния озер... (2006-2016).

\section{Методика}

Все исследователи, чьи работы привлечены к анализу, а также автор данной работы пользовались, в большинстве своем, описанными ниже методами.

На всех трех озерах при отборе проб применяли, в основном, принцип разрезов и полуразрезов от берега к наибольшей глубине: на оз. Нарочь и Мястро точки отбора проб закладывались с шагом глубин через каждые 2 м и на оз. Баторино - через 1 м. При отборе проб по Программе экологического мониторинга закладывались две точки - прибрежный и глубинный биотоп на каждом озере.

Отбор проб проводили чаще в течение вегетационного сезона с апреля по ноябрь (в разные годы разные исследователи выбирали свои сроки и определяли количество отбираемых проб), иногда пробы отбирались и в зимние месяцы со льда.

На песчаных и плотных грунтах для отбора проб бентосных животных использова- 
ли ковшовый дночерпатель системы Петерсена, при работе на мягких илах применяли дночерпатель Экмана-Берджа в модификации Боруцкого с высоким (до $40 \mathrm{~cm}$ ) коробом и площадью захвата $0,025 \mathrm{~m}^{2}$. На каждой станции отбирали не менее двух дночерпательных проб. В июле 1999 г., наряду с ковшовыми дночерпателями систем Петерсона и Боруцкого, мы применяли трубчатый дночерпатель (площадью захвата $0,009 \mathrm{~m}^{2}$ ) на глубинах от 1 до 5,5 м с густыми зарослями макрофитов. Сравнивая результаты отбора проб дночерпателями, мы убедились, что в ковшовых сборах преобладает фитофильная фауна, а в пробах бентоса, отобранных трубчатым дночерпателем, - пелофильная. Это говорит о том, что ковшовые дночерпатели захватывают основную массу подводных зарослей и незначительно заглубляются в ил, а трубчатый дночерпатель, напротив, раздвигая растения, отбирает почти чистый ил, уходя глубоко в субстрат. Добытый грунт отмывался через промывалку, обшитую мельничным ситом № 23.

К макрозообентосу относили животных с размерами от 3 мм и более. Основные группы животных, по которым велось сравнение: личинки хирономид, олигохеты, моллюски, ракообразные (для оз. Нарочь - 3 вида: Pallasea quadrispinosa (Sars, 1967); Gammarus lacustris (Fabricius, 1776) и Asellus aquaticus (Linnaeus, 1758) и, для озер Мястро и Баторино - 2 вида: A. aquaticus и G. lacustris) и прочие организмы (личинки насекомых кроме хирономид, клещи, пиявки, плоские черви, а также Gordius aquaticus (Linnaeus, 1758)).

Биомассу отдельных групп зообентоса определяли взвешиванием на торсионных весах после обсушивания на фильтровальной бумаге до исчезновения мокрых пятен. Личинок крупных форм ручейников взвешивали без домиков, мелких форм двустворча- тых моллюсков (до 10 мм) - без надрезания или прокалывания раковин, больших моллюсков и дрейссену, попавших в дночерпатель, с 1997 г. учитывали отдельно. Взвешивание всех животных проводили спустя 3 месяца после их фиксации, так как за это время их вес стабилизируется (Методы определения..., 1968). Численность и биомасса донных животных пересчитана на площадь дна $\left(1 \mathrm{~m}^{2}\right)$ в зависимости от их распределения по исследованным глубинам в соответствии с морфометрическими данными озер, т.е. везде приведены средняя взвешенная численность и биомасса бентоса.

\section{Результаты и обсуждение}

Для анализа изменений в структуре макрозообентоса Нарочанских озер по имеющимся результатам исследований всех авторов, изучавших его когда-либо в период, анализируемый автором данной работы (19472015 гг.), рассматриваются следующие этапы в эволюционном трофическом статусе озер: первый период относительно ненарушенного состояния экосистемы озер с 1947 по 1969 гг. (Экологическая система..., 1985), второй - до 1983 г. - период антропогенного эвтрофирования, следующий, с 1984 по 1989 г., - деэвтрофирования и в 1990-2015 гг., когда произошло вселение и массовое развитие моллюскафильтратора Dreissena polymorpha (Pallas 1771) и началась бентификация озер. Третий и последний период деэвтрофикационной эволюции озер связан еще и со снижением биогенной нагрузки в результате реализации Государственной программы комплексного использования и охраны водных и земельных ресурсов (Адамович и др., 2017a).

\section{Видовой состав}

Видовой состав донных и фитофильных беспозвоночных животных озер Нарочан- 
ской группы, по данным различных авторов (Н.Л. Сокольской (1954) - олигохет в оз. Нарочь; С.И. Гаврилова - олигохет в оз. Мястро и Баторино; И.И. Десятика (1975) - моллюсков в трех озерах; М.М. Драко (1954, 1956), С.И. Гаврилова (1973) и частично И.П. Арабиной (1968) - хирономид), приведен в (Экологическая система..., 1985). Я.И. Старобогатовым изучалась фауна моллюсков окрестностей Нарочанской биостанции БГУ в 1958 г. (неопубликованные данные). Е.С. Шалапенок (1964) описала фауну водных насекомых литорали оз. Нарочь. С.И. Гаврилов и И.И. Десятик (1975) привели список видов брюхоногих моллюсков оз. Нарочь. А.Д. Писаненко (1985) дал фаунистический очерк о стрекозах. Таксономическая характеристика беспозвоночных - гидробионтов Нарочанского региона - дана в обзорной статье Е.С. Шалапенок и др. (2013) по спискам дипломных работ, подготовленных под ее руководством. Она же рассмотрела фауну пиявок оз. Нарочь (Шалапенок, 2003). Г.М. Тищиков приводит список зообентоса по результатам отбора проб в 1999 г. на створе Нарочь в районе санатория «Сосны» (неопубликованные данные). В.А. Мищенков (2012а, б) дополнил список видового состава моллюсков оз. Нарочь новыми видами рода Radix (Gastropoda: Lymnaeidae: R. (Lymnaea) ampla (Hartmann, 1821) и $R$. (Lymnaea) balthica (Linnaeus 1758). Видовые списки макрозообентоса озер автор данной работы по результатам своих исследований публикует ежегодно с 2006 г. в «Бюллетенях экологического состояния озер...» (2006-2016).

Детально сравнивать изменение видового богатства бентосных сообществ исследованных озер на протяжении изучаемого периода, на наш взгляд, не совсем корректно, так как исследователи ставили различные цели при изучении и оценке развития зообентоса. К примеру, видовой список насекомых (стрекозы-Odonata, ручейники - Trichoptera, водные жуки - Coleoptera), приводимый Е.С. Шалапенок, А.Д. Писаненко, включал взрослые и личиночные формы животных, обитающих в окрестностях изучаемых озер. Они, однако, могли и не встречаться в конкретных озерах, но могли развиваться вблизи этих и других водоемов. Другие же авторы давали основной обзор видов донных беспозвоночных, встреченных в качественных и количественных пробах зообентоса, отобранных именно в озерах Нарочь, Мястро и Баторино.

Всего в изучаемых озерах за период исследований с 1954 по 2015 гг. по результатам всех исследователей отмечено 394 таксона животных, отнесенных к макробентосным беспозвоночным, принадлежащим к 26 систематическим группам, из них в оз. Нарочь 373 , в оз. Мястро - 223, в оз. Баторино - 155 таксонов (здесь и далее к таксонам отнесены организмы разного таксономического ранга, до которого были определены представители макрозообентоса). Разными специалистами до вида определено 323 , до рода -64 , до отряда -2 , до подкласса -2 и до класса -3 . По данным результатов наблюдений разных лет, внутри указанного выше периода исследователи отмечали следующее количество таксонов: в 1959-1978 гг. - 152, 106 и 71 в озерах Нарочь, Мястро, Баторино соответственно. При этом наиболее изученными были моллюски, олигохеты и хирономиды. По числу видов эти группы животных распределялись в озерах Нарочь, Мястро, Баторино следующим образом: моллюски - 50, 29, 22; олигохеты - 42, 33, 21; хирономиды - 46, 35, 20 соответственно (Экологическая система..., 1985). В 1954-1973 гг. во всех трех озерах было зарегистрировано 278 таксонов беспозвоночных животных, включая виды, отмеченные Е.С. Шалапенок и А.Д. Писаненко. Из этого ко- 
личества в оз. Нарочь выявлено 267; в оз. Мястро - 114 и в оз. Баторино - 71 таксон. С 1975 по 1985 г. упоминаются в оз. Нарочь -88 ; в оз. Мястро - 61 и в оз. Баторино - 46 таксонов макрозообентоса. По данным собственных сборов автора на протяжении 1997-2015 гг. в озерах определено 206 таксонов донных и фитофильных беспозвоночных. Не определялись олигохеты и водные клещи, до родов и семейств были определены некоторые личинки насекомых. В оз. Нарочь отмечен 181 таксон; в оз. Мястро - 154 и Баторино - 114 .

Из озер Нарочанской группы наибольшим таксономическим богатством зообентосных организмов отличается мезотрофное оз. Нарочь (373), промежуточные величины отмечены для эвтрофного оз. Мястро (223) и наименьшие - для высокоэвтрофного оз. Баторино (155 таксонов). Основные морфометрические и трофические характеристики озер приведены в работе (Экологическая система..., 1985). Рассматривая распределение видового состава бентоса по озерам, можно сказать, что в разные годы во всех трех водоемах встречались 142 общих таксона. В озерах Мястро и Баторино, соединенных довольно длинной и зарастающей из года в год протокой, - 7 общих таксонов; тогда как в соседних озерах Нарочь и Мястро, сообщающихся более короткой и быстро текущей протокой, отмечен 61 общий таксон. В озерах Нарочь и Баторино еще меньше общих животных 5 таксонов. Только для оз. Нарочь за все годы исследований отмечено 164 специфичных таксона, для оз. Мястро - 11 и для оз. Баторино специфичен только 1 таксон. Сравнительно высокое таксономическое богатство донных и фитофильных животных, встреченных в о3. Нарочь, можно объяснить наибольшей изученностью этого водного объекта и большим количеством разнообразных биоценозов, характерных для озера. Заслуживает внимания факт нахождения в оз. Нарочь реликтового рачка Pallasiola quadrispinosa (G.O. Sars, 1867) (= Pallasea quadrispinosa (Sars, 1967)), впервые отмеченного И.П. Арабиной, обитающего на глубинах от 7 до 12 м и часто встречающегося в пробах на протяжении ряда лет наблюдений с 1997 по 2015 г.

\section{Количественные характеристики}

Величины средневзвешенных общих биомасс и плотности поселения зообентоса в целом для озер за рассматриваемые годы (с 1947 по 2015 г.) исследований имеют такие показатели: в оз. Нарочь - 15,67 и 1,48; в оз. Мястро $-12,47$ и 1,58 и в оз. Баторино $-9,73$ г $/ \mathrm{M}^{2}$ и 0,90 тыс. экз $/ \mathrm{M}^{2}$. Эти же показатели по нашим собственным исследованиям в 1997-2015 гг. были наибольшими в оз. Нарочь - 14,77 и 2,57; промежуточные величины отмечены для оз. Мястро - 7,82 и 1,48 и наименьшие

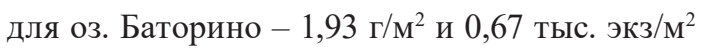
(табл. 1). Объясняется это наличием более широкой литоральной зоны в оз. Нарочь по сравнению с озерами Мястро и Баторино. На песках мелководья и в зарослях макрофитов этих озер обитает больше всего бентосных животных. В оз. Нарочь площадь дна, ограниченная изобатой глубин до 7 м, в основном занята зарослями погруженных в воду макрофитов и охватывает $41,6 \%$ от общей площади дна озера; в оз. Мястро вследствие более низкой прозрачности воды растения распространены до 4-5 м, занимая при этом площадь дна около $30,8 \%$, а в оз. Баторино изреженные заросли едва достигают 1,5 м глубины, могут произрастать только на 19,6 \% от всей площади дна озера.

Показатели средневзвешенной биомассы почти всегда были бо́льшими в оз. Нарочь и в прежние годы, промежуточные значения они имели в оз. Мястро и были меньшими в оз. Баторино, исключая ряд лет (1983, 1990, 


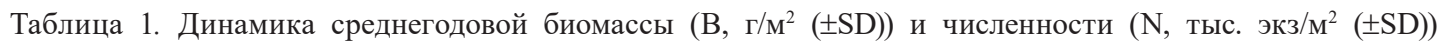
зообентоса в озерах Нарочь, Мястро и Баторино в разные периоды проводимых исследований

Table 1. The annual biomass $\left(\mathrm{B}, \mathrm{g} / \mathrm{m}^{2}( \pm \mathrm{SD})\right)$ and abundance $\left(\mathrm{N}\right.$, thousand individuals $\left./ \mathrm{m}^{2}( \pm \mathrm{SD})\right)$ of zoobenthos in the lakes Naroch, Myastro, and Batorino at different periods

\begin{tabular}{|l|c|c|c|c|c|c|}
\hline \multirow{2}{*}{ Период } & \multicolumn{2}{|c|}{ оз. Нарочь } & \multicolumn{2}{c|}{ оз. Мястро } & \multicolumn{2}{c|}{ оз. Баторино } \\
\cline { 2 - 7 } & $\mathrm{N}$ & $\mathrm{B}$ & $\mathrm{N}$ & $\mathrm{B}$ & $\mathrm{N}$ & $\mathrm{B}$ \\
\hline \multicolumn{7}{|c|}{ Данные для периодов, изучавшихся разными авторами } \\
\hline $1947-1949$ гг. & $1,21 \pm 0,71$ & $25,39 \pm 8,99$ & $1,79 \pm 1,07$ & $11,65 \pm 2,87$ & $1,47 \pm 0,91$ & $9,35 \pm 2,83$ \\
\hline $1959-1965$ гг. & $0,66 \pm 0,18$ & $10,59 \pm 1,91$ & $0,63 \pm 0,28$ & $3,52 \pm 1,70$ & $0,32 \pm 0,09$ & $2,07 \pm 2,01$ \\
\hline $1967-1969$ гг. & $0,27 \pm 0,04$ & $9,49 \pm 1,47$ & $0,13 \pm 0,02$ & $3,58 \pm 1,17$ & 0,07 & $1,20 \pm 0,82$ \\
\hline $1968 ; 1975-1977$ гг. & - & $7,50 \pm 2,04$ & - & $2,92 \pm 2,43$ & - & $1,05 \pm 0,90$ \\
\hline $1983 ; 1985-1989$ гг. & 1,75 & 6,99 & $1,02 \pm 0,50$ & $12,77 \pm 6,14$ & $0,54 \pm 0,31$ & $5,84 \pm 2,29$ \\
\hline $1990 ; 1992 ; 1994$ гг. * & $1,47 \pm 1,05$ & $20,13 \pm 20,15$ & $2,44 \pm 1,78$ & $36,44 \pm 5,88$ & $1,16 \pm 0,44$ & $34,27 \pm 34,32$ \\
\hline $1997-2015$ гг. & $2,57 \pm 0,63$ & $14,77 \pm 4,27$ & $1,48 \pm 0,73$ & $7,82 \pm 4,47$ & $0,67 \pm 0,48$ & $1,93 \pm 0,79$ \\
\hline \multicolumn{7}{|c|}{ Данные для разных периодов эволюции трофического статуса озер } \\
\hline $1947-1969$ гг. & $0,71 \pm 0,47$ & $15,16 \pm 8,88$ & $0,85 \pm 0,85$ & $6,25 \pm 4,68$ & $0,62 \pm 0,75$ & $4,21 \pm 4,48$ \\
\hline $1975-1983$ гг. & - & $7,50 \pm 2,04$ & - & $2,92 \pm 2,43$ & - & $1,05 \pm 0,90$ \\
\hline $1984-1990$ гг. & 1,75 & 6,99 & $1,02 \pm 0,50$ & $12,77 \pm 6,14$ & $0,54 \pm 0,31$ & $5,84 \pm 2,29$ \\
\hline $1990-2015$ гг. & $2,02 \pm 0,78$ & $17,45 \pm 3,79$ & $1,96 \pm 0,68$ & $22,13 \pm 20,24$ & $0,92 \pm 0,35$ & $18,10 \pm 22,87$ \\
\hline \multicolumn{7}{|c|}{ Данные за весь период исследований } \\
\hline $1947-2015$ гг.
\end{tabular}

Примечания: «-» означает отсутствие данных, т.к. авторы для указанных периодов приводят только биомассу бентоса, но не указывают его численность;

* численность и биомасса приводятся с учетом дрейссены.

1992, 1994, 1997, 1998 и 2000 гг.), когда значения средней биомассы макрозообентоса в о3. Мястро превышали, и порой значительно, таковые в оз. Нарочь. В некоторые годы (1990, 1992 и 1994 гг.) биомасса бентоса была выше и в оз. Баторино по сравнению с оз. Нарочь. Существенное влияние на экосистему Нарочанских озер в этот период наблюдений оказали два фактора: снижение биогенной нагрузки на водоемы (Остапеня и др., 2012) и массовое развитие во всех трех озерах дрейссены. Второй фактор, как отмечали авторы проводимых тогда исследований В.П. Ляхнович и Н.Г. Еремова (Остапеня и др., 1993; Остапеня и др., 1994a, 1994б), по-видимому, сыграл руководящую роль в развитии бентоса в этих озерах. Так, преобладающим в макрозообентосе озер Мястро и Баторино в то время стал представитель понто-каспийского комплекса - моллюск D. polymorpha. Благодаря массовому развитию дрейссены в те годы в озерах наблюдалась отчетливая тенденция нарастания общей биомассы макрофауны.

Достаточно высокие значения биомасс отмечались в ряду наблюдений с 1947 по 1949 г. и в 1990, 1992 и 1994 гг. Эти высокие показатели объясняются тем, что одни авторы исследований учитывали крупные формы моллюсков в количественных пробах макрозообентоса, тогда как другие преимущественно мелких моллюсков, относя крупные экземпляры только к учету видового состава, или их количественные характеристики приводили отдельно от остального макрозообентоса. В промежутке лет с 1990 по 1994 г. увеличение биомасс 
связывали со вселением и массовым развитием дрейссены в озерах. В оз. Нарочь с периода 1947-1969 гг. к периоду 1997-2015 гг. наблюдалось некоторое увеличение средней общей численности макрозообентоса при сравнительно неизменной биомассе, что говорит об уменьшении индивидуальных масс организмов в озере.

Сравнение вклада основных групп макрозообентоса в его количественное развитие в исследуемых озерах мы проводили по данным всех указанных выше авторов, за исключением данных И.И. Десятика за 1967-1969 гг.; В.П. Ляхновича и Н.Г. Еремовой за 1983, 1985-1989 гг., которые тогда не вели этого анализа. Это сравнение показало, что весомую роль в численности и биомассе общего бентоса оз. Нарочь играют моллюски $(24,7$ и 54,6 \%) и хирономиды (50,0 и 25,0 \%). В оз. Мястро в биомассе преобладают моллюски $(44,1 \%)$, в биомассе $(36,4 \%)$ и численности (60,3\%) хирономиды, и только в численности еще олигохеты $(18,0$ \%). В оз. Баторино видное место занимают по биомассе и численности хирономиды $(54,4$ и $37,1 \%)$, по биомассе моллюски $(33,9$ \%), а по численности организмы, вошедшие в группу прочих (17,9%) (см. выше Методику). В оз. Нарочь значительные значения вклада в биомассу беспозвоночных также имели прочие организмы (11,5 \%) и ракообразные $(4,8 \%)$; в оз. Мястро и в оз. Баторино - прочие организмы (11,3 и 21,5 \%) и олигохеты (8,0 и 7,5%). Такое распределение животных по группам указывает на принадлежность этих озер к хирономидному типу при достаточно высокой численности малакофауны в оз. Нарочь. Кроме того, заметный вклад ракообразных и личинок ручейников (входящих в группу прочих животных) лишний раз подчеркивает более высокое качество воды в оз. Нарочь по сравнению с озерами Мястро и Баторино, где шире распростране- ны личинки хаоборин (из группы прочих) и олигохеты (табл. 2).

В оз. Нарочь из рассматриваемых групп зообентоса в 1997-2015 гг. биомасса и численность хирономид снизилась в 1,3 и 1,4 раза, олигохет - увеличилась в 2,5 и 1,1 раза по сравнению с периодом 1947-1949 гг. Только с 1959 г. в пробах оз. Нарочь отмечались ракообразные, и с этого времени их биомасса и численность возросли в 2,5 и 1,9 раза к $1997-$ 2015 г. В оз. Мястро и Баторино до 1997 г. также не были приведены данные по группе ракообразных, в то время как с 1997 по 2015 гг. в указанных озерах, хотя и не каждый год, но отмечались в количественных сборах представители класса Crustacea и их вклад в общую среднюю численность и биомассу бентоса составил в оз. Мястро 0,6 и 1,1%; в о3. Баторино 0,3 и 0,6 \% соответственно. В о3. Мястро к периоду 1997-2015 гг. несколько уменьшилась численность олигохет - в 1,1 раза, биомасса олигохет - в 1,7 раза, численность и биомасса хирономид - в 1,3 раза; численность и биомасса моллюсков выросла в 1,7 и 1,5 раз, организмов из группы прочие в 2,6 и 1,4 раза соответственно по сравнению с 1947-1949 гг. В оз. Баторино за аналогичный период снизились численность и биомасса моллюсков в 1,3 и 2,7 раза, а эти же показатели для хирономид выросли в 1,3 и 2,7 раза. Складывающаяся ситуация перераспределения по группам бентоса на различных этапах эволюции озер может свидетельствовать о возрастании в них илонакопления.

Участие хищников в численности и биомассе общего макробентоса наибольшее в о3. Баторино - 35,9 и 41,0 \%, меньшее в оз. Мястро - 21,3 и 19,5 \% и незначительно в оз. Нарочь - 11,0 и 8,5 \%. Процент животных по типу питания в общей средней биомассе организмов немного отличался в озерах на протяжении многих лет наблюдений (табл. 3). 


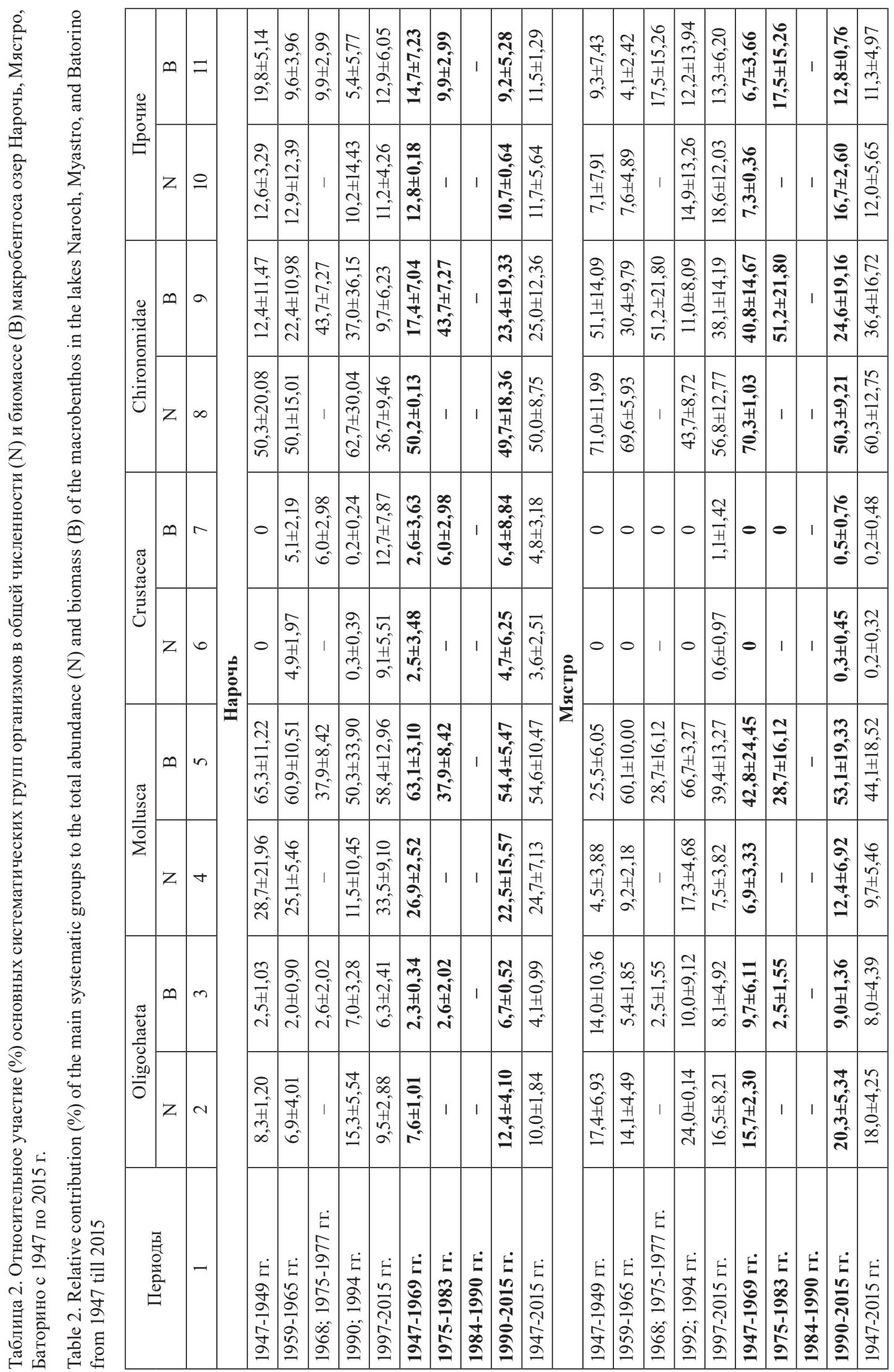




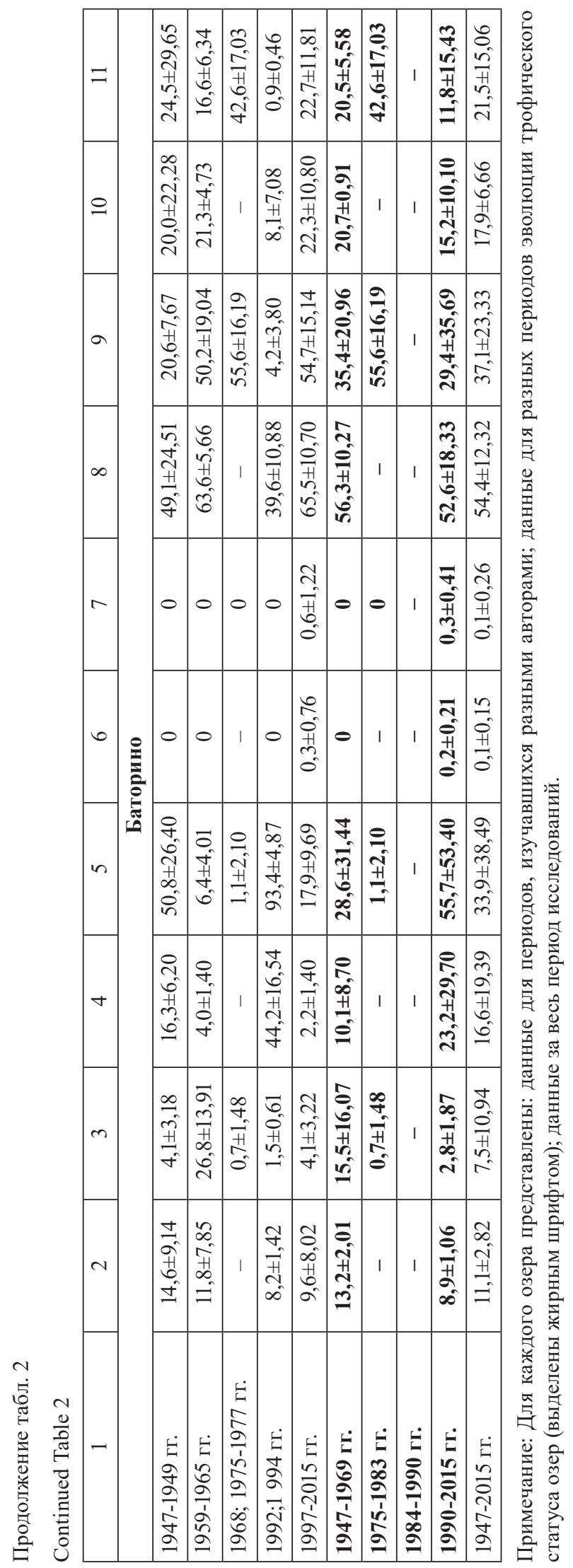


Таблица 3. Относительное участие (\%) в общей численности $(\mathrm{N})$, биомассе $(\mathrm{B})$ животных с разным типом питания в озерах в 1964-2015 гг.

Table 3. Relative contribution (\%) to total abundance (N) and biomass (B) of animals with different food habits in lakes from 1964 till 2015

\begin{tabular}{|c|c|c|c|c|}
\hline \multirow{2}{*}{ Периоды } & \multicolumn{2}{|c|}{ Мирные } & \multicolumn{2}{|c|}{ Хищные } \\
\hline & $\mathrm{N}, \%$ & $\mathrm{~B}, \%$ & $\mathrm{~N}, \%$ & $\mathrm{~B}, \%$ \\
\hline \multicolumn{5}{|c|}{ Нарочь } \\
\hline 1964-1965 гг. & - & $95,4 \pm 2,18$ & - & $4,6 \pm 2,18$ \\
\hline 1968, 1975-1977 гг. & - & $92,5 \pm 2,92$ & - & $7,5 \pm 2,92$ \\
\hline 1997-2015 гг. & $89,0 \pm 3,75$ & $86,7 \pm 5,74$ & $11,0 \pm 3,75$ & $13,3 \pm 5,74$ \\
\hline 1964-2015 гг. & - & $91,5 \pm 4,43$ & - & $8,5 \pm 4,44$ \\
\hline \multicolumn{5}{|c|}{ Мястро } \\
\hline 1964-1965 гг. & - & $74,3 \pm 0,74$ & - & $26,2 \pm 0,02$ \\
\hline 1968, 1975-1977 гг. & - & $79,4 \pm 9,01$ & - & $20,6 \pm 9,01$ \\
\hline 1997-2015 гг. & $78,7 \pm 5,56$ & $88,1 \pm 3,98$ & $21,3 \pm 5,56$ & $11,9 \pm 3,98$ \\
\hline 1964-2015 гг. & - & $80,6 \pm 6,98$ & - & $19,5 \pm 7,20$ \\
\hline \multicolumn{5}{|c|}{ Баторино } \\
\hline 1964-1965 гг. & - & $54,2 \pm 11,43$ & - & $45,8 \pm 11,39$ \\
\hline 1968, 1975-1977 гг. & - & $53,7 \pm 17,43$ & - & $46,3 \pm 17,43$ \\
\hline 1997-2015 гг. & $64,0 \pm 13,34$ & $69,0 \pm 13,54$ & $35,9 \pm 13,34$ & $31,0 \pm 13,54$ \\
\hline 1964-2015 гг. & - & $59,0 \pm 8,65$ & - & $41,0 \pm 8,86$ \\
\hline
\end{tabular}

В оз. Нарочь с периода 1964-1965 гг. к 1977 г. биомасса хищного бентоса выросла в 1,6 раза и с 1977 г. к 1997-2015 гг. - в 2,9 раза. С периода 1964-1965 гг. к 1997-2015 гг. в о3. Мястро и Баторино, напротив, биомасса хищников уменьшилась в 2,2 и в 1,5 раза.

\section{Дрейссена как фактор изменения}

структуры макрозообентоса

В середине 1980-х гг. в системе Нарочанских озер появилась дрейссена. Следует подчеркнуть, что в связи с колонизацией озер этим моллюском резко снизилась численность унионид. Так, все найденные в 1993 г. униониды были покрыты скоплениями дрейссен, что вызвало их массовую гибель (Каратаев, Бурлакова, 1995). К тому же появление и интенсивное развитие дрейссены оказывает воздействие на все звенья водной экосистемы, вызывая изменения в их структуре и функ- ционировании. Фильтрационная активность дрейссены способствует усилению продукционных характеристик донных сообществ за счет сдвига процессов продуцирования органического вещества в придонные слои и осаждения взвешенного органического вещества из толщи воды на дно (Остапеня и др., 2012).

В дночерпательных пробах макрозообентоса с 2005 по 2015 г. этого моллюска учитывали отдельно, в остальные годы, с 1985 по 1994, - D. polymorpha включали в группу моллюсков. В табл. 4 приведены средние значения плотности и биомассы дрейссены в оз. Нарочь на различных глубинах. Из таблицы видно, что максимальная средняя плотность и биомасса моллюска находится на глубине 3-4 м в густых зарослях харовых водорослей.

В озерах Мястро и Баторино в местах отбора количественных проб дрейссена 
Таблица 4. Средние величины $( \pm \mathrm{SD})$ плотности $\left(\mathrm{N}\right.$, тыс. экз $\left./ \mathrm{M}^{2}\right)$ и биомассы $\left(\mathrm{B}, \Gamma / \mathrm{M}^{2}\right)$ дрейссены по данным дночерпательных проб оз. Нарочь с 2005 по 2015 г.

Table 4. The average values $( \pm \mathrm{SD})$ of abundance $\left(\mathrm{N}\right.$, thousand individuals $\left./ \mathrm{m}^{2}\right)$ and biomass $\left(\mathrm{B}, \mathrm{g} / \mathrm{m}^{2}\right)$ of zebra mussels from the lake Naroch Ponar samples collected from 2005 till 2015

\begin{tabular}{|c|c|c|c|c|c|c|}
\hline \multirow{2}{*}{ Показатель } & \multicolumn{7}{|c|}{ Глубина, м } \\
\cline { 1 - 7 } & $0-2$ & $3-4$ & $5-6$ & $7-8$ & $9-10$ & $11-12$ \\
\hline $\mathrm{N}$ & $0,09 \pm 0,08$ & $3,01 \pm 3,63$ & $0,60 \pm 0,82$ & $0,08 \pm 0,13$ & $0,04 \pm 0,09$ & $0,01 \pm 0,02$ \\
\hline $\mathrm{B}$ & $51,16 \pm 60,46$ & $267,91 \pm 186,18$ & $43,79 \pm 48,47$ & $55,55 \pm 180,19$ & $47,81 \pm 98,25$ & $4,05 \pm 13,43$ \\
\hline
\end{tabular}

Таблица 5. Средневзвешенные величины $( \pm \mathrm{SD})$ плотности $\left(\mathrm{N}\right.$, тыс. экз $\left./ \mathrm{M}^{2}\right)$, биомассы $\left(\mathrm{B}, \mathrm{r}^{2}\right)$ и вклад дрейссены в общий бентос по данным дночерпательных проб оз. Нарочь, Мястро и Баторино с 2005 по 2015 г.

Table 5. Weighted average values $( \pm \mathrm{SD})$ of Dreissena abundance $\left(\mathrm{N}\right.$, thousand individuals $\left./ \mathrm{m}^{2}\right)$, biomass $\left(\mathrm{B}, \mathrm{g} / \mathrm{m}^{2}\right)$, and contribution to total benthos according to Ponar samples collected in lakes Naroch, Myastro, and Batorino from 2005 till 2015

\begin{tabular}{|l|c|c|c|c|c|c|}
\hline \multirow{2}{*}{\multicolumn{1}{|c|}{ Показатель }} & \multicolumn{2}{|c|}{ Оз. Нарочь } & \multicolumn{2}{c|}{ Оз. Мястро } & \multicolumn{2}{c|}{ Оз. Баторино } \\
\cline { 1 - 7 } & $\mathrm{N}$ & $\mathrm{B}$ & $\mathrm{N}$ & $\mathrm{B}$ & $\mathrm{N}$ & $\mathrm{B}$ \\
\hline Средние & $0,44 \pm 0,54$ & $51,21 \pm 41,32$ & $0,01 \pm 0,03$ & $0,95 \pm 1,80$ & $0,01 \pm 0,02$ & $4,21 \pm 9,05$ \\
\hline $\begin{array}{l}\text { Доля в общем } \\
\text { бентосе (\%) }\end{array}$ & $12,40 \pm 13,15$ & $65,86 \pm 24,02$ & $1,02 \pm 2,29$ & $11,10 \pm 13,38$ & $2,76 \pm 3,98$ & $67,74 \pm 40,91$ \\
\hline
\end{tabular}

попадалась редко, хотя надо отметить, что на некоторых ограниченных участках литоральной зоны указанных озер наблюдается большее или меньшее скопление моллюска при наличии подходящего для его закрепления субстрата: в оз. Баторино это участки в р-не д. Шиковичи, д. Азарки; в о3. Мястро - в р-не Дендросада, д. Гирины, д. Минчаки. В этих озерах в последнее десятилетие (2005-2015 гг.), по-видимому, идет снижение численности вселенца, но здесь чаще стали встречаться другие крупные двустворчатые моллюски аборигенных родов Anodonta и Unio. Напротив, в оз. Нарочь с 1999 по 2015 г. крайне редко отмечали присутствие представителей унионид, исключая протоку, соединяющую оз. Нарочь с оз. Мястро, где на протяжении указанных сроков наблюдений постоянно встречались в небольших количествах живые униониды, иногда сильно колонизированных дрейссеной.

В дночерпательных пробах 2009, 2010 и 2011 гг. в озерах Мястро и Баторино дрейссена вообще не была отмечена. В период с 2005 по 2015 г. в оз. Мястро она попадалась преимущественно на глубинах от 1 до 4 м, а в оз. Баторино до 2 м. Средние за эти годы численность и биомасса моллюска в оз. Мястро на

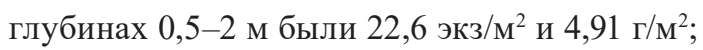
на 3-4 м - 53,2 и 1,34; в оз. Баторино на глубинах 0,5-2 м соответственно 65,7 экз $/ \mathrm{M}^{2}$ и 29,16 г/м². Между тем средние за 11 лет по озерам показатели средневзвешенных плотностей и биомасс дрейссены были наибольшими в о3. Нарочь (табл. 5).

В период массового развития дрейссены в оз. Нарочь, динамика общей биомассы зообентоса практически полностью повторяет динамику биомассы дрейссены. Это не уди- 
вительно, если учесть, что вклад дрейссены в общую биомассу в период 1997-2008 гг. составил 85,5 \%, а в период 2009-2015 гг. 68,4 \% (Адамович и др., 2017б). Высок вклад биомассы дрейссены в общую биомассу зообентоса и в дночерпательных пробах оз. Баторино - 67,7 \% в среднем за 2005-2015 гг., тогда как в оз. Мястро за этот период наблюдений он незначителен - 11,1 \%. Объясняется это тем, что и так незначительная часть биомассы бентоса в оз. Баторино перекрывается весом крупных экземпляров моллюска, хотя вклад в общую среднюю численность его не так велик $-2,8$ \%. Вместе с тем, массовое развитие дрейссены изменило количественное соотношение некоторых групп зообентоса. В трех озерах к настоящему времени увеличился процент ракообразных в численности и биомассе общего бентоса (см. выше Количественные характеристики). Биомасса макрозообентоса без учета дрейссены выросла во всех трех озерах (см. табл. 1).

\section{Заключение}

В статье впервые обобщены разрозненные исследования макрозообентоса озер Нарочь, Мястро, Баторино, выполненных разными специалистами в разные годы, а также собственные исследования автоpa (с 1997 г. по настоящее время). Всего в изучаемых озерах за период исследований с 1954 по 2015 г. отмечено 394 таксона животных, принадлежащих к 26 систематическим группам, из них в оз. Нарочь -373 , в оз. Мястро - 223, в оз. Баторино - 155 таксонов. Величины средневзвешенных общих биомасс и плотности зообентоса в целом для озер за рассматриваемый период составили: в оз. Нарочь - 15,67 и 1,48; в оз. Мястро -

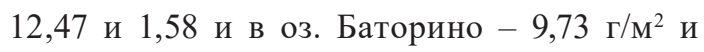
0,90 тыс. экз/м². Показатели средневзвешен- ной биомассы почти всегда были большими в оз. Нарочь, наименьшими - в оз. Баторино. Оз. Мястро занимало промежуточное положение.

Существенное влияние на экосистему Нарочанских озер, включая и структуру макрозообентоса, оказали два фактора: снижение биогенной нагрузки на водоемы и массовое развитие во всех трех озерах дрейссены. Второй фактор, по-видимому, сыграл решающую роль в развитии бентоса: в этот период изменилось количественное соотношение некоторых доминирующих групп. По сравнению с периодом 1947-1949 гг. в оз. Нарочь снизилась биомасса и численность хирономид (в 1,3 и 1,4 раза), но увеличились эти показатели для олигохет (в 2,5 и 1,1 раза соответственно). В оз. Мястро несколько уменьшились численность и биомасса олигохет (в 1,1 и 1,7 раза) и хирономид (в 1,3 раза), но выросли численность и биомасса моллюсков (в 1,7 и 1,5 раза) и организмов из группы прочие (в 2,6 и 1,4 раза). В оз. Баторино численность и биомасса моллюсков стала ниже в 1,3 и 2,7 раза, а для хирономид эти показатели увеличились в 1,3 и 2,7 раза. Структурные изменения в составе макробентоса озер могут указывать на ускорение процессов илонакопления. Следует также отметить, что биомасса макрозообентоса без учета дрейссены выросла во всех трех озерах.

Учитывая то, что с момента вселения дрейссены в Нарочанские озера прошло уже около 30 лет, первостепенной задачей является полномасштабная оценка современного состояния популяции этого моллюска в разных биотопах, а также более глубокий анализ изменений, происходящих в различных группах зообентоса, с оценкой их адаптационных способностей, вызванных длительным влиянием дрейссены. 
Автор весьма благодарен зав. НИЛ гидроэкологии канд. биол. наук Б.В. Адамовичу за стимулирование автора к написанию данной работы, доктору биол. наук, главному научному сотруднику Т.М. Михеевой за редактирование рукописи, ценные советы и помощц по улучиению качества статьи, а также сотрудникам Нарочанской биологической станции Э.П. Жукову, А.Ю. Азаренкову, И.А. Коротышевскому за помощц в отборе проб.

\section{Список литературы}

Адамович Б.В., Жукова Т.В., Михеева Т.М., Ковалевская Р.З., Макаревич Т.А., Жукова А.А. (2017а) Эвтрофирование, олиготрофикация и бентификация в Нарочанских озерах: 40 лет мониторинговых исследований. Журнал Сибирского федерального университета. Биология, 4: 379-394 [Adamovich B.V., Zhukova T.V., Mikheyeva T.M., Kovalevskaya R.Z., Makarevich T.A., Zhukova H.A. (2017a) Eutrophication, oligotrophication, and benthiphication in Naroch Lakes: 40 years of monitoring. Journal of Siberian Federal University. Biology [Zhurnal Sibirskogo federalnogo universiteta. Biologiya], 4: 379-394 (in Russian)]

Адамович Б.В., Макаревич О.А., Жукова Т.В. (2017б) Дрейссена как фактор изменения структуры макрозообентоса оз. Нарочь. Сборник статей международной научно-практической конференции, посвященной памяти професора К.М. Ельского. Гродно, 15-17 марта 2017 г. Гродно, ГрГУ им Я. Купалы, с. 8-11 [Adamovich B.V., Makarevich O.A., Zhukova T.V. (2017b) Dreissena as a factor of the macrozoobentos structure changes in Naroch Lake. Proceedings of the International Conference dedicated to the memory of Professor K.M. Yelsky. Grodno, March 15-17, 2017. Grodno, Yanka Kupala State University of Grodno, p. 8-11 (in Russian)]

Арабина И.П. (1968) Сезонная, годовая динамика и продукция зообентоса озер Нарочь, Мястро и Баторино. Дис... канд. биол. наук. Минск, 191 с. [Arabina I.P. (1968) Seasonal and annual zooplankton dynamic and production in lakes Naroch, Myastro, Batorino. Dis. ... Cand. Biol. Sciences. Minsk, 191 p. (in Russian)]

Бюллетень экологического состояния озер Нарочь, Мястро, Баторино (2006-2012) А.П. Остапеня, Т.В. Жукова, Т.М. Михеева и др., под общ. ред. А.П. Остапени. Минск, БГУ [Bulletin of ecological state of lakes Naroch, Myastro, Batorino (2006-2012) Ostapenya A.P., Zhukova T.V., Mikheyeva T.M. et al. (eds.), Ostapenya A.P. (chief editor) Minsk, BSU (in Russian)]

Бюллетень экологического состояния озер Нарочь, Мястро, Баторино (2013-2016) Т.В. Жукова, Т.М. Михеева, Р.З. Ковалевская и др., под общ. ред. Т.М. Михеевой. Минск, БГУ [Bulletin of ecological state of lakes Naroch, Myastro, Batorino (2013-2016) Zhukova T.V., Mikheyeva T.M., Kovalevskaya R.Z. et al. (eds), Mikheyeva T.M. (chief editor) Minsk, BSU (in Russian)]

Гаврилов С.И. (1969) Продуктивность зообентоса некоторых промысловых озер Белоруссии. Дис...канд. биол. наук. Минск, 253 с. [Gavrilov S.I. (1969) Productivity of zoobenthos of some fishing lakes of Belorussia. Dis. ... Cand. Biol. Sciences. Minsk, 253 p. (in Russian)]

Гаврилов С.И., Десятик И.И. (1975) Брюхоногие моллюски озера Нарочь. Вестник БГУ, Серия 2, 3: 47-50 [Gavrilov S.I., Desyatik I.I. (1975) Gastropod mollusks of the Naroch Lake. Bulletin of BSU, Series 2 [Vestnik BGU, Seriya 2], 3: $47-50$ (in Russian)]

Десятик И.И. (1975) Моллюски Белорусского поозерья и их роль в биологической продуктивности озер. Дис...канд. биол. наук. Минск, 182 с. [Desyatik I.I. (1975) Mollusks of the Belarusian

$$
-193-
$$


Lake District and their role in the biological productivity of lakes. Dis. ... Cand. Biol. Sciences. Minsk, 182 p. (in Russian)]

Драко М.М. (1953) Видовой состав, количественное развитие и кормовое значение донной фауны (бентоса) промысловых озер БССР. Дис... канд. биол. наук. Минск [Drako M.M. (1953) Species composition, quantitative development and fodder value of benthic fauna of fishing lakes of BSSR. Dis.... Cand. Biol. Sciences. Minsk (in Russian)]

Каратаев А.Ю., Бурлакова Л.Е. (1995) Роль дрейссены в озерных экосистемах. Экология, 3: 232-236 [Karataev A.Y., Burlakova L.E. (1995) Role of Dreissena polymorpha (Pallas) in lakes ecosystems. Ecology [Ehkologiya], 3: 232-236 (in Russian)]

Методы определения продукции водных животных (1968) Винберг Г.Г. (ред.) Минск, 248 с. [The methods for the estimation of production of aquatic animals (1968) Winberg G.G. (ed.) Minsk, 248 p. (in Russian)]

Мищенков В.А. (2012a) Морфологические особенности моллюсков рода Radix (Gastropoda: Lymnaeidae) озера Нарочь. Вестник БГУ, Серия 2, 2: 34-38 [Mishchenkov V.A. (2012) Morphological features of mollusks of the genus Radix (Gastropoda: Lymnaeidae) of Lake Naroch. Bulletin of $B S U$, Series 2 [Vestnik BGU, Seriya 2], 2: 34-38 (in Russian)]

Мищенков В.А. (2012б) Морфологические особенности двух форм моллюсков Radix sp. (Gastropoda: Lymnaeidae), обнаруженных в озере Нарочь. Навукові записки Тернопільского національного педагогічного університету імені Володимира Гнатюка, Серія: біологія, 2(51): 186-189 [Mishchenkov V.A. (2012) Morphological features of two forms of mollusks Radix sp. (Gastropoda: Lymnaeidae) discovered in Lake Naroch. Scientific notes of the Ternopil National Pedagogical University named after Volodymyr Hnatyuk, Series: Biology [Navukovi zapiski Ternopilskogo nacionalnogo pedagogichnogo universitetu imeni Volodimira Gnatyuka, Seriya biologiya], 2(51): 186-189 (in Russian)]

Остапеня А.П., Ковалевская Р.З., Михеева Т.М., Макаревич Т.А., Жукова А.А., Лукьянова Е.В., Никитина Л.В., Макаревич О.А., Дубко Н.В., Карабанович В.С., Савич И.В., Верес Ю.К. (2012) Бентификация озерной экосистемы: причины, механизмы, возможные последствия, перспективы исследований. Труды БГУ, 7 (часть 1): 135-148 [Ostapenya A.P. Mikheyeva T.M., Kovalevskaya R.Z., Makarevich T.A., Zhukova A.A., Lukyanova E.V., Nikitina L.V., Makarevich O.A., Dubko N.V., Karabanovich V.S., Savich I.V., Veres Yu.K. (2012) Bentification of the Lake ecosystem: causes, mechanisms, possible consequences, prospects for research. Proceedings of BSU [Trudy BGU], 7 (part 1): 135-148 (in Russian)]

Остапеня А.П., Ковалев А.А., Жукова Т.В., Михеева Т.М., Бабицкий В.А., Крючкова Н.М., Ковалевская Р.З., Костюкович С.Б., Инкина Г.А., Макаревич Т.А., Жуков Э.П., Иконников В.Ф., Самусенко А.М., Орловский А.Ф., Рачевский А.Н., Якушко О.Ф. (1993) Экологический паспорт озера Нарочь. Минск, Экомир Пресс, 95 с. [Ostapenya A.P., Kovalev A.A., Zhukova T.V., Mikheyeva T.M., Babitsky V.A., Kryuchkova N.M., Kovalevskaya R.Z., Kostyukovich S.B., Inkina G.A., Makarevich T.A., Zhukov E.P., Ikonnikov V.F., Samusenko A.M., Orlovsky A.F., Rachevsky A.N., Yakushko O.F. (1993) Ecological passport of Lake Naroch. Minsk, EcoMir Press, 95 p. (in Russian)]

Остапеня А.П., Ковалев А.А., Михеева Т.М., Бабицкий В.А., Жукова Т.В., Крючкова Н.М., Ковалевская Р.З., Костюкович С.Б., Инкина Г.А., Макаревич Т.А., Жуков Э.П., Иконников В.Ф., 
Самусенко А.М., Орловский А.Ф., Рачевский А.Н., Якушко О.Ф. (1994а) Экологический паспорт озера Мястро. Минск, Экомир Пресс, 44 с. [Ostapenya A.P., Kovalev A.A., Mikheyeva T.M., Babitsky V.A., Zhukova T.V., Kryuchkova N.M., Kovalevskaya R.Z., Kostyukovich S.B., Inkina G.A., Makarevich T.A., Zhukov E.P., Ikonnikov V.F., Samusenko A.M., Orlovsky A.F., Rachevsky A.N., Yakushko O.F. (1994a) Ecological passport of Lake Myastro. Minsk, EcoMir Press, 44 p. (in Russian)]

Остапеня А.П., Ковалев А.А., Михеева Т.М., Бабицкий В.А., Жукова Т.В., Крючкова Н.М., Ковалевская Р.З., Костюкович С.Б., Инкина Г.А., Макаревич Т.А., Жуков Э.П., Иконников В.Ф., Самусенко А.М., Орловский А.Ф., Рачевский А.Н., Якушко О.Ф. (1994б) Экологический паспорт озера Баторино. Минск, Экомир Пресс, 43 с. [Ostapenya A.P., Kovalev A.A., Mikheyeva T.M., Babitsky V.A., Zhukova T.V., Kryuchkova N.M., Kovalevskaya R.Z., Kostyukovich S.B., Inkina G.A., Makarevich T.A., Zhukov E.P., Ikonnikov V.F., Samusenko A.M., Orlovsky A.F., Rachevsky A.N., Yakushko O.F. (1994b) Ecological passport of Lake Batorino. Minsk, EcoMir Press, 43 p. (in Russian)]

Писаненко А.Д. (1985) Фаунистический очерк стрекоз (Insecta, Odonata) Белоруссии. Becmник БГУ, Серия 2, 3: 144-146 [Pisanenko A.D. (1985) Faunistic sketch of dragonflies (Insecta, Odonata) of Belarus. Bulletin of BSU, Series 2 [Vestnik BGU, Seriya 2], 3: 144-146 (in Russian)]

Экологическая система Нарочанских озер (1985) Винберг Г.Г. (ред.) Минск, Университетское, 303 с. [Ecological system of the Naroch Lakes (1985) Vinberg G.G. (ed.) Minsk, Universitetskoye, 303 p. (in Russian)]

Шалапенок Е.С. (1964) Фауна водных насекомых литорали оз. Нарочь. Биологические основы рыбного хозяйства на внутренних водоемах Прибалтики. Минск, с. 196-201 [Shalopenok E.S. (1964) Fauna of aquatic insects of littoral of Lake Naroch. Biological basis of fisheries in the inland waters of the Baltic States. Minsk, p. 196-201 (in Russian)]

Шалапенок Е.С., Солодуха Е.А., Буга С.В., Жукова Т.В. (2013) Таксономическая направленность и основные результаты эколого-фаунистических исследований беспозвоночных - гидробионтов Нарочанского региона на кафедре зоологии БГУ. Вестник БГУ, Серия 2, 3: 60-65 [Shalopenok E.S., Soloducha E.A., Buga S.V., Zhukova T.V. (2013) Taxonomic directivity and main results of ecologo-faunistic studies of invertebrate hydrobionts of the Naroch region at the Department of Zoology of the BSU. Bulletin of BSU, Series 2 [Vestnik BGU, Seriya 2], 3: 60-65 (in Russian)]

Шалапенок Е.С. (2003) Материалы к фауне пиявок озера Нарочь. Материаль II Международной научной конференции «Озерные экосистемы: биологические процессы, антропогенная трансформация, качество водыр. Минск - Нарочь 22-26 сентября 2003 г. Минск, с. 534536 [Shalopenok E.S. (2003) Materials on the fauna of the leeches of Lake Naroch. Proceedings of the II International Scientific Conference «Lake ecosystems: biological processes, anthropogenic transformation, water quality». Minsk-Naroch, September 22-26, 2003. Minsk, p. 534-536 (in Russian)] 